\title{
KECERNAAN IN SACCO HIJAUAN LEGUMINOSA DAN HIJAUAN NON- LEGUMINOSA DALAM RUMEN SAPI PERANAKAN ONGOLE
}

\section{IN SACCO DIGESTIBILITY OF LEGUME AND NON-LEGUME FORAGES IN RUMEN OF ONGOLE GRADE COWS}

\author{
Rendi Fathoni Hadi*, Kustantinah, dan Hari Hartadi \\ Fakultas Peternakan, Universitas Gadjah Mada, Jl. Fauna No. 3, Bulaksumur, Yogyakarta, 55281
}

\section{INTISARI}

\begin{abstract}
Penelitian ini bertujuan untuk menggali potensi hijauan pakan ternak secara optimal, laju degradasi nutrien pakan di dalam rumen dari berbagai hijauan yang biasa diberikan oleh peternak. Bahan pakan dalam penelitian ini adalah 7 macam bahan pakan hijauan daun gamal (GL), daun sawo (SW), daun turi putih (TP), daun beringin (BR), daun kaliandra (KL), daun nangka (NG), dan daun coklat (CO). Data yang diambil adalah kecernaan nutrien meliputi bahan kering (BK), bahan organik (BO), protein kasar (PK), neutral detergent fiber (NDF), dan acid detergent fiber (ADF). Sampel diinkubasi dalam rumen ternak yang berfistula dengan interval waktu yang berbeda yaitu inkubasi: 2, 4, 8, 12, 16, 24, 36 dan 48 jam. Data yang diperoleh dianalisis menggunakan analisis variansi pola searah. Hasil perhitungan in sacco rumen didapatkan nilai degradasi teori (DT) dari BK GL sebesar 60,06\%; SW 34,78\%; TP 73,96\%; BR 41,40\%; KL 43,80\%; NG 43,67\%; dan CO 28,67\%. Hasil perhitungan in sacco rumen didapatkan nilai DT dari BO GL sebesar 59,13\%; SW 32,74\%; TP 73,07\%; BR 42,83\%; KL 44,18\%; NG 45,04\%; dan CO 26,80\%. Hasil perhitungan in sacco rumen didapatkan nilai DT dari PK GL sebesar 66,14\%; SW 32,49\%; TP 81,46\%; BR 42,89\%; KL 31,84\%; NG 47,05\%; dan CO 29,46\%. Hasil perhitungan in sacco rumen didapatkan nilai DT dari NDF GL sebesar 46,84\%; SW 46,59\%; TP 56,69\%; BR 44,18\%; KL 23,01\%; NG 30,07\%; dan CO 55,43\%. Hasil perhitungan in sacco rumen didapatkan nilai DT dari ADF GL sebesar 61,27\%; SW 43,95\%; TP 56,53\%; BR 40,11\%; KL 21,08\%; NG 44,66\%; dan CO 69,15\%. Hasil uji statistik menunjukkan adanya perbedaan nyata $(\mathrm{P}<0,05)$ pada degradasi BK, BO, PK, NDF, dan ADF. Disimpulkan bahwa tidak semua leguminosa memiliki nilai DT fraksi BK, BO, PK, NDF, dan ADF yang lebih tinggi daripada tanaman non-leguminosa. Ada kecenderungan bahwa makin lama waktu tinggal di dalam rumen maka degradasinya akan semakin meningkat.
\end{abstract}

(Kata kunci: Leguminosa, Non-leguminosa, In sacco rumen)

\begin{abstract}
This study was aimed to explore the optimum potential of forage and the degradation rate the rumen of nutrient of forage (legume and non legume) derived different forage fodder used farmers. Seven forages i.e. Gliricidia (GL), Manilkara (SW), Sesbania (TP), Ficus (BR), Calothyrsus (KL), Jackfruit (NG), and Cacao leaves (CO), were used in this experiment. Samples were incubated in the rumen of fistulated cattle with different time intervals, namely 2, 4, 8 , $12,16,24,36$, and 48 hours. The collected data were the nutrient digestibility residues in rumen, including dried matter $(D M)$, organic matter $(O M)$, crude protein (CP), neutral detergent fiber (NDF), and acid detergent fiber (ADF). Data were analyzed using Completely Randomized Design (CRD). From the calculation of in sacco rumen, it was obtained the degradation theory (DT) values of DM: GL 60.06\%; SW 34.78\%; TP 73.96\%; BR 41.40\%; KL 43.80\%; NG $43.67 \%$; and CO $28.67 \%$. From in sacco rumen calculation, it was obtained the DT values of OM : GL 59.13\%; SW $32.74 \%$; TP 73.07\%; BR 42.83\%; KL 44.18\%; NG 45.04\%; and CO 26.80\%. Calculation of in sacco rumen showed the DT values of CP : GL 66.14\%; SW 32.49\%; TP 81.46\%; BR 42.89\%; KL 31.84\%; NG 47.05\%; and CO 29.46\%. The calculation of in sacco rumen, it was obtained the DT values of NDF: GL 46.84\%; SW 46.59\%; TP 56.69\%; BR 44.18\%; KL 23.01\%; NG 30.07\%; and CO 55.43\%. From the calculation of in sacco rumen, it was obtained the DT values of ADF: GL 61.27\%; SW 43.95\%; TP 56.53\%; BR 40.11\%; KL 21.08\%; $N G 44.66 \%$; and CO 69.15\%. There were significant differences $(P<0.05)$ on the degradation of $D M, O M, C P, N D F$, and $A D F$. It is concluded that not all of legume has higher $D T$ values of $D M, O M, C P, N D F$, and $A D F$ fraction than non-legume. There is a tendency that the longer retention time in the rumen, the higher degradation rate.
\end{abstract}

(Keywords: Legume, Non-legume, In sacco rumen)

\footnotetext{
*Korespondensi (corresponding author):

Telp. +62 8564741 7010, E-mail: sapi_alonso@yahoo.com
} 


\section{Pendahuluan}

Pakan utama yang biasanya diberikan oleh peternak disebut hijauan makanan ternak merupakan semua bahan pakan yang berasal dari tanaman, terdiri dari bentuk daun-daunan, atau kadang-kadang masih bercampur batang, ranting serta bunga-bunganya, yang umumnya berasal dari tanaman sebangsa rumput (gramineae), kacangkacangan (leguminosae), limbah pertanian, atau dedaunan hijauan dari tumbuhan lainnya. Leguminosa merupakan jenis tanaman pakan ternak yang mengandung protein tinggi yang sangat dibutuhkan untuk pertumbuhan dan produktivitas ternak. Selain leguminosa, ada juga hijauan pakan lain (non-leguminosae) yang biasa diberikan seperti daun nangka, daun sawo, daun beringin, daun coklat, daun jambu air, daun pepaya, daun pisang, dan lain-lainnya. Pakan hijauan pakan yang diberikan pada ternak biasanya mempunyai kandungan nutrien yang berbeda-beda. Keistimewaan tanaman leguminosa dibandingkan dengan tanaman hijauan pakan lain adalah kandungan proteinnya yang tinggi, sebaliknya kandungan serat kasarnya (karbohidrat struktural) lebih rendah. Adanya perbedaan komposisi kimia tanaman selain mempengaruhi kecernaan juga akan berpengaruh terhadap keseimbangan laju degradasi di dalam rumen sehingga potensinya untuk dapat dimanfaatkan oleh ternak dapat ditentukan dengan uji kecernaan.

Pakan ruminansia yang berupa hijauan difraksinasi menjadi bagian dinding sel dan isi sel, dimana setelah dikonsumsi maka ada sebagian dinding sel yang dapat di degradasi oleh mikrobia dan sebagian lolos ke saluran post rumen, sedangkan untuk isi sel, sebagian besar dapat di degradasi oleh mikrobia di dalam rumen dan hanya sebagian kecil yang lolos dari degradasi rumen (Kustantinah, 2008). Menurut Orskov (1992), sifat fisik bahan pakan dan lingkungan rumen merupakan faktor utama yang menentukan karakteristik degradasi bahan tersebut dalam rumen. Sifat-sifat yang dimaksud meliputi kelarutan bahan pakan, laju degradasi di dalam rumen (outflow rate), tingkat konsumsi, ketersediaan substrat terfermentasi, populasi mikrobia, ukuran partikel, bentuk fisik, dan $\mathrm{pH}$ rumen. Berdasarkan uraian tersebut maka perlu dilakukan penelitian mengenai degradasi secara in sacco di dalam rumen beberapa hijauan pakan ternak baik yang termasuk leguminosa dan non-leguminosa.

\section{Materi dan Metode}

Ternak yang digunakan dalam penelitian adalah dua ekor sapi betina Peranakan Ongole (PO) yang berfistula pada rumen dan duodenum dengan berat badan $\pm 280 \mathrm{~kg}$ yang dipelihara di kandang. Alat yang digunakan selama penelitian adalah mesin cuci, timbangan pakan merk Fine Goat dengan kapasitas $5 \mathrm{~kg}$ dan kepekaan $100 \mathrm{~g}$, timbangan pegas, oven, kantong nilon, cincin chrome (dengan berat $675 \mathrm{~g}$ ), seperangkat alat analisis proksimat, timbangan elektrik merk Mettler PM 460 dengan kepekaan 0,001 g, dan Wiley mill dengan diameter lubang saringan $3 \mathrm{~mm}$. Ransum terdiri dari hijauan dan konsentrat dengan imbangan 80 : 20, dengan kandungan PK ransum 12,39\%. Ransum diberikan pada jam 09.00 WIB dan 16.00 WIB, sedangkan air diberikan secara ad libitum.

\section{Preparasi sampel}

Hijauan yang digunakan diambil bagian edible portion seperti bagian daun, tangkai daun, batang daun serta bagian yang masih dapat dikunyah oleh ternak (ternak kambing). Sampel hijauan dikeringkan menggunakan oven $55^{\circ} \mathrm{C}$, selanjutnya sampel digiling menggunakan Wiley mill dengan menggunakan saringan berdiameter 3 $\mathrm{mm}$. Kantong nilon/polyester yang akan diinkubasikan dalam rumen mempunyai porositas $46 \mu \mathrm{m}$ berukuran $6 \times 11 \mathrm{~cm}$ dan direkatkan menggunakan pemanas pada ketiga sisinya, diberi label/tanda sesuai dengan ternak, jenis pakan, waktu inkubasi dan ulangan untuk inkubasi rumen. Kantong kemudian dikeringkan dengan oven pada suhu $55^{\circ} \mathrm{C}$ hingga beratnya konstan dan ditimbang berat kosongnya. Selanjutnya sampel seberat $5 \mathrm{~g}$ dimasukkan ke dalam kantong untuk inkubasi rumen dan penutupan kantong dengan karet.

\section{Pengukuran degradasi di rumen}

Kantong yang sudah siap kemudian ditali menggunakan karet mentah pada sisi yang berlubang kemudian sampel ditautkan dengan tali plastik/nilon pada cincin yang terbuat dari besi yang dilapisi chrome (675 g). Panjang tali yang digunakan berukuran 40-60 cm. Inkubasi dimulai pada pagi hari sebelum ransum pagi diberikan (pukul 07.00 WIB), maksimal pada setiap sapi terdiri 32 kantong. Sampel yang dimasukkan ke dalam rumen ternak yang berfistula adalah sampel dengan interval waktu inkubasi yang berbeda yaitu 2, 4, 8, $12,16,24,36$, dan 48 jam. Kemudian sampel pakan dan sisa residu diuji di laboratorium berupa analisis proksimat bahan $\mathrm{BK}$, BO, dan PK berdasarkan AOAC (2005). Data nilai degradasi nutrien BK, $\mathrm{BO}, \mathrm{PK}$, dinding sel (NDF) dan isi sel (ADF) yang didapat dimasukkan ke dalam persamaan: $p=a+b$ $\left(1-\mathrm{e}^{-\mathrm{ct}}\right)$ dengan $\mathrm{p}$ adalah jumlah kumulatif yang terdegradasi pada waktu t, a adalah fraksi yang cepat terlarut/terdegradasi (\%), b adalah fraksi yang potensial didegradasi dalam rumen (\%), c adalah 
laju degradasi fraksi b (\%/jam), dan $\mathrm{t}$ adalah waktu (jam). Data untuk degradasi di dalam rumen dianalisis variansi menggunakan analisis Rancang Acak Lengkap (RAL) pola searah, kemudian apabila terdapat perbedaan nyata sebagai efek dari perlakuan dilanjutkan dengan uji Duncan's New Multiple Range Test (DMRT).

\section{Hasil dan Pembahasan}

\section{Komposisi kimia bahan pakan}

Hijauan pakan yang diidentifikasi dan dievaluasi ada 7 jenis, dimana hijauan tersebut merupakan hijauan yang sering diberikan peternak baik berupa leguminosa dan hijauan lain (nonleguminosa) yang diperoleh dari vegetasi alam maupun yang dibudidayakan. Jenis hijauan leguminosa yang digunakan seperti daun gamal, daun turi putih, dan daun kaliandra, sedangkan jenis nonleguminosa seperti daun beringin, daun nangka, daun sawo, dan daun coklat. Hasil analisis bahan pakan hijauan (leguminosa dan non-leguminosa) yang digunakan mempunyai kandungan nutrien yang berbeda-beda baik nutrien BK, BO, PK, NDF, ADF, dan hemiselulosa (Tabel 1).

\section{Degradasi pakan di dalam rumen}

Degradasi bahan kering. Hasil analisis variansi menunjukkan bahwa nilai DT dari BK antara ke tujuh jenis hijauan pakan didapatkan hasil yang berbeda nyata $(\mathrm{P}<0,05)$ dan perbedaan yang tidak nyata (Tabel 2). Nilai DT bahan kering dari bahan hijauan pakan dari kelompok leguminosa seperti turi putih, gamal dan kaliandra lebih tinggi daripada kelompok jenis non-leguminosa (hijauan lain) walaupun pada hijauan pakan kaliandra didapatkan hasil yang tidak berbeda nyata dengan hijauan pakan beringin. Jenis leguminosa seperti turi putih mempunyai nilai DT sebesar $73,96 \%$, gamal sebesar 60,06\% dan nilai DT sebesar $43,80 \%$ untuk kaliandra, sedangkan nilai DT untuk hijauan lain (non-leguminosa) seperti nangka mempunyai nilai DT $43,67 \%$, diikuti beringin, sawo dan coklat masing-masing mempunyai nilai DT sebesar 41,40; 34,78; dan $28,67 \%$.

Nilai DT bahan kering dari bahan hijauan pakan dari kelompok legume seperti turi putih, gamal, dan kaliandra lebih tinggi daripada kelompok non-leguminosa (hijauan lain) walaupun pada hijauan pakan kaliandra didapatkan hasil yang tidak berbeda nyata dengan hijauan pakan beringin. Makin tinggi kandungan PK maka nilai fraksi cepat larut akan semakin besar karena PK yang tersedia akan dimanfaatkan oleh mikrobia rumen untuk perkembangannya di dalam rumen. Menurut Jung et al. (1996), ternak ruminansia dapat mencerna 40-70\% bahan kering di dalam dinding sel, nilai ini sangat bervariasi $20-40 \%$ untuk tanaman leguminosa dan 50-80\% untuk tanaman rumput-rumputan.

Degradasi maksimum $(a+b)$ untuk fraksi BK hijauan pakan turi putih, gamal, nangka, dan beringin menunjukkan hasil yang mendekati maksimum, karena nilai $(a+b)$ hampir sama nilai pada inkubasi 48 jam (TP: 88,98\% vs 87,69\%; GL: $78,82 \%$ vs $78,61 \%$; NG: $54,57 \%$ vs $53,65 \%$; dan BR: $52,47 \%$ vs $51,47 \%$ ). Untuk kaliandra, sawo dan coklat nilai $(a+b)$ lebih besar daripada kinetika kehilangan pada inkubasi 48 jam (KL: $61,81 \%$ vs 57,05\%; SW: $43,76 \%$ vs $41,34 \%$; dan CO: $43,76 \%$ vs $39,78 \%$ ), hal ini menunjukkan bahwa belum terjadi degradasi secara maksimum.

Degradasi bahan organik. Hasil analisis variansi dari nilai DT BO menunjukkan perbedaan nyata $(\mathrm{P}<0,05)($ Tabel 3$)$. Nilai fraksi yang mudah larut $(a)$ dan fraksi yang potensial terdegradasi $(b)$ serta laju fraksi yang potensial terdegradasi (c) dan DT dari turi putih, gamal, nangka, kaliandra, beringin, sawo, dan coklat tersaji pada Tabel 3. Dilihat dari nilai DT ketujuh jenis hijauan pakan

Tabel 1. Komposisi kimia hijauan pakan yang digunakan dalam penelitian (\% BK) (chemical composition of forage used in the study $(\% D M)$ )

\begin{tabular}{lrrrrrr}
\hline \hline \multirow{2}{*}{ Nama sampel (sample name) } & \multicolumn{7}{c}{$100 \%$ BK $(\%$ DM) } \\
\cline { 2 - 7 } & BK & BO & \multicolumn{1}{c}{ PK } & NDF & ADF & Hemiselulosa \\
\hline Turi putih (Sesbania glandiflora) & 20,43 & 92,43 & 23,76 & 35,21 & 24,00 & 11,21 \\
Gamal (Gliricidia sepium) & 22,92 & 90,14 & 23,70 & 30,06 & 19,82 & 10,24 \\
Kaliandra (Calliandra calothyrsus) & 35,23 & 92,34 & 21,16 & 49,19 & 32,59 & 16,60 \\
Beringin (Ficus benjamina) & 17,47 & 84,17 & 9,29 & 44,42 & 32,20 & 12,22 \\
Nangka (Artocarpus heterophyllus) & 39,32 & 83,03 & 12,50 & 24,74 & 16,72 & 8,02 \\
Sawo (Manilkara zapota) & 32,56 & 91,07 & 10,12 & 37,34 & 28,08 & 9,26 \\
Coklat (Theobroma cacao L.) & 38,92 & 88,34 & 10,52 & 59,62 & 45,36 & 14,26 \\
\hline
\end{tabular}

BK: bahan kering (dry matter), BO: bahan organik (organic matter), PK: protein kasar (crude protein),

NDF: neutral detergent fiber, ADF: acid detergent fiber. 
Tabel 2. Fraksi $a, b, c$, dan degradasi teori (DT) dari BK bahan pakan hijauan (fraction $a, b, c$, and DM degradation theory (DT) of forage feedstuffs)

\begin{tabular}{lcccc}
\hline \hline \multicolumn{1}{c}{ Nama sampel (sample name) } & $a$ & $b$ & $c$ & DT (Kp 5\%) \\
\hline Turi putih (Sesbania glandiflora) & 51,72 & 37,26 & 0,07 & $73,96^{\mathrm{a}}$ \\
Gamal (Gliricidia sepium) & 13,91 & 64,91 & 0,12 & $60,06^{\mathrm{b}}$ \\
Kaliandra (Calliandra calothyrsus) & 29,38 & 32,43 & 0,04 & $43,80^{\mathrm{c}}$ \\
Nangka (Artocarpus heterophyllus) & 27,99 & 26,58 & 0,07 & $43,67^{\mathrm{c}}$ \\
Beringin (Ficus benjamina) & 26,79 & 25,69 & 0,07 & $41,40^{\mathrm{c}}$ \\
Sawo (Manilkara zapota) & 27,25 & 16,51 & 0,04 & $34,78^{\mathrm{d}}$ \\
Coklat (Theobroma cacao L.) & 16,59 & 27,17 & 0,04 & $28,67^{\mathrm{e}}$ \\
\hline
\end{tabular}

a,b,c,d,e Superskrip yang berbeda pada kolom yang sama menunjukkan adanya perbedaan yang nyata $(\mathrm{P}<0,05)$ (different superscripts at the same column indicate significant differences $(P<0.05)$ ).

Tabel 3. Fraksi $a, b$, c dan degradasi teori (DT) dari BO bahan pakan hijauan (fraction $a, b, c$, and OM degradation theory (DT) of forage feedstuffs)

\begin{tabular}{lcccc}
\hline \hline \multicolumn{1}{c}{ Nama sampel (sample name) } & $a$ & $b$ & $c$ & DT (Kp 5\%) \\
\hline Turi putih (Sesbania glandiflora) & 50,48 & 37,86 & 0,07 & $73,07^{\mathrm{a}}$ \\
Gamal (Gliricidia sepium) & 16,86 & 61,31 & 0,11 & $59,13^{\mathrm{b}}$ \\
Nangka (Artocarpus heterophyllus) & 30,06 & 27,47 & 0,06 & $45,04^{\mathrm{c}}$ \\
Kaliandra (Calliandra calothyrsus) & 29,16 & 33,78 & 0,04 & $44,18^{\mathrm{c}}$ \\
Beringin (Ficus benjamina) & 25,45 & 28,96 & 0,08 & $42,83^{\mathrm{c}}$ \\
Sawo (Manilkara zapota) & 24,98 & 17,00 & 0,04 & $32,74^{\mathrm{d}}$ \\
Coklat (Theobroma cacao L.) & 14,53 & 27,61 & 0,04 & $26,80^{\mathrm{e}}$ \\
\hline a,b,c,d,e
\end{tabular}

$\overline{a, b, c, d, e}$ Superskrip yang berbeda pada kolom yang sama menunjukkan adanya perbedaan yang nyata $(\mathrm{P}<0,05)$

(different superscripts at the same column indicate significant differences $(P<0.05)$ ).

maka bahan pakan turi putih mempunyai nilai tertinggi sebesar $73,07 \%$, kemudian diikuti oleh gamal, nangka, kaliandra, beringin, sawo, dan coklat, masing-masing mempunyai nilai DT sebesar $59,13 \%$; 45,04\%; 44,18\%; 42,83\%; 32,74\%; dan $26,80 \%$.

Adanya perbedaan nilai $a, b, c$, dan DT antara jenis hijauan leguminosa dapat disebabkan karena perbedaan komposisi nutrien. Dengan demikian terlihat bahwa prosentase kehilangan BO pada bahan pakan leguminosa tidak selalu lebih tinggi dari bahan pakan hijauan non-leguminosa (Tabel 3). Waktu tinggal di dalam rumen yang semakin lama akan mengakibatkan meningkatnya kontak antara pakan dengan mikrobia rumen, hal ini akan memungkinkan aktivitas mikrobia rumen semakin besar dalam mendegradasi pakan. Keterkaitan keduanya dapat memperkecil nilai laju degradasi fraksi potensial terdegradasi. Perbedaan fraksi potensial larut dan laju degradasi fraksi potensial terdegradasi dipengaruhi oleh komposisi nutrien pakan, lama tinggal pakan didalam rumen dan juga ketersediaan substrat untuk aktivitas mikrobia dalam mendegradasi pakan di dalam rumen. Tanaman hijauan non-leguminosa sebagian besar merupakan tanaman pepohonan yang mempunyai kandungan lignin yang cukup kuat dan dapat berikatan dengan selulosa dan hemiselulosa. Bagian yang memiliki jaringan kayu dari tanaman seperti janggel, kulit keras, biji, bagian serabut kasar, akar, batang, dan daun mengandung substansi yang kompleks dan tidak dapat dicerna disebut lignin. Pada tanaman muda lapisan matriks ini terdiri dari selulosa dan hemiselulosa, tetapi pada tanaman tua matriks dilapisi lignin dan polisakarida lain (Hartadi et al., 2008). Hal ini sesuai dengan pernyataan Thomaszewska et al. (1993) bahwa komposisi nutrien baik antar jenis tanaman maupun varietas tanaman yang sama mempunyai kandungan proporsi dinding sel (selulosa, hemiselulosa, dan lignin) yang berbeda.

Degradasi maksimum $(a+b)$ untuk fraksi BO hijauan pakan turi putih, gamal, dan beringin menunjukkan hasil yang mendekati maksimum, karena nilai $(a+b)$ hampir mendekati nilainya pada inkubasi 48 jam (TP: $88,34 \%$ vs $87,02 \%$; GL: $78,17 \%$ vs $77,86 \%$; dan BR: $54,41 \%$ vs $53,79 \%$ ). Untuk nangka, kaliandra, sawo dan coklat nilai $(a+b)$ lebih besar daripada kinetika kehilangan pada inkubasi 48 jam (NG: 57,53\% vs 55,99\%; KL: $62,95 \%$ vs $57,99 \%$; SW: $41,97 \%$ vs $39,49 \%$; dan CO: $42,14 \%$ vs $38,09 \%$ ). Hal ini menunjukkan bahwa belum terjadi degradasi secara maksimum pada hijauan pakan nangka, kaliandra, sawo, dan coklat sehingga masih membutuhkan waktu $>48$ jam untuk maksimal degradasinya. 
Degradasi protein kasar. Hasil analisis variansi nilai degradasi PK menunjukkan adanya perbedaan nyata $(\mathrm{P}<0,05)$ (Tabel 4). Nilai fraksi yang mudah larut $(a)$ dan fraksi yang potensial terdegradasi (b) serta laju fraksi yang potensial terdegradasi (c) dan DT dari turi putih, gamal, nangka, beringin, sawo, kaliandra, dan coklat tersaji pada Tabel 4.

Dilihat dari nilai DT ketujuh jenis hijauan pakan, turi putih (TP) mempunyai nilai tertinggi sebesar 81,46\%, kemudian diikuti oleh gamal, nangka, beringin, sawo, kaliandra, dan coklat masing-masing mempunyai nilai DT sebesar 66,14\%, 47,05\%, 42,89\%, 32,49\%, 31,84\%, dan $29,46 \%$. Perbedaan fraksi $b$ dan $c$ dipengaruhi oleh komposisi nutrien hijauan baik leguminosa dan nonleguminosa. Karakteristik pakan juga memiliki pengaruh terhadap besar kecilnya laju degradasi fraksi potensial terdegradasi, pakan yang mengandung fraksi mudah larut dalam rumen akan memberikan nilai fraksi $c$ yang berbeda dengan pakan yang sedikit mengandung fraksi mudah larut.

Adanya perbedaan nilai $a, b, c$, dan DT antara jenis hijauan leguminosa dapat disebabkan karena perbedaan komposisi nutrien. Dengan demikian terlihat bahwa persentase kehilangan PK pada bahan pakan leguminosa lebih tinggi dari bahan pakan hijauan non-leguminosa (Tabel 4). Selain itu juga di dapatkan nilai laju degradasi bahan pakan jenis turi putih, gamal, kaliandra (leguminosa) lebih tinggi daripada bahan pakan beringin, nangka, sawo, dan coklat dari kelompok hijauan nonleguminosa. Menurut Thomaszewska et al. (1993), bagian terbesar dinding sel adalah selulosa, hemiselulosa, dan lignin, dimana terdapat selulosa yang potensial tercerna dan yang tidak dapat dicerna (lignoselulosa). Kualitas suatu bahan pakan juga ditentukan oleh komposisi kimianya, disamping juga dipengaruhi oleh ada tidak atau besar kecilnya anti kualitas atau anti nutrisi pada bahan pakan tersebut (Soejono et al., 2002).
Degradasi maksimum $(a+b)$ untuk fraksi PK terjadi pada hijauan pakan turi putih dan gamal yang menunjukkan hasil mendekati maksimum, karena nilai $(a+b)$ hampir mendekati nilainya pada inkubasi 48 jam (TP: 96,44\% vs 95,60\%; dan GL: $89,69 \%$ vs $89,32 \%$ ). Untuk nangka, beringin, sawo, kaliandra, dan coklat nilai $(a+b)$ lebih besar daripada kinetika kehilangan pada inkubasi 48 jam (NG: $73,09 \%$ vs $66,30 \%$; BR: $58,13 \%$ vs $55,48 \%$; SW: $47,75 \%$ vs $41,75 \%$; KL: $56,71 \%$ vs $47,16 \%$; dan CO: $42,67 \%$ vs $37,54 \%$ ), hal ini menunjukkan bahwa belum terjadi degradasi secara maksimum. Untuk itu pada hijauan pakan nangka, beringin, sawo, kaliandra, dan coklat masih harus membutuhkan waktu lebih dari 48 jam untuk mendegradasi protein kasar.

Degradasi neutral detergent fiber. Hasil analisis variansi dari nilai DT nilai degradasi NDF menunjukkan adanya perbedaan nyata $(\mathrm{P}<0,05)$ (Tabel 5). Nilai fraksi yang mudah larut $(a)$ dan fraksi yang potensial terdegradasi $(b)$ serta untuk laju fraksi yang potensial terdegradasi (c) dan DT dari turi putih, coklat, gamal, sawo, beringin, nangka, dan kaliandra tersaji pada Tabel 5.

Dilihat dari nilai DT NDF ke tujuh jenis hijauan pakan maka bahan pakan turi putih mempunyai nilai tertinggi sebesar 56,69\%, kemudian diikuti oleh coklat dengan nilai DT sebesar 55,43\%; dan berturut-turut gamal $46,84 \%$; sawo 46,59\%; beringin 44,18\%; nangka $30,07 \%$; dan kaliandra merupakan salah satu jenis legume yang memiliki nilai DT terendah yaitu sebesar $23,01 \%$. Dari ke tujuh jenis hijauan pakan baik jenis leguminosa maupun hijauan non-leguminosa memiliki kandungan NDF yang berbeda-beda sehingga dapat mempengaruhi nilai fraksi $a, b, c$, dan DT (Tabel 5). Dengan demikian terlihat bahwa persentase kehilangan NDF pada bahan pakan leguminosa tidak selalu lebih tinggi daripada bahan pakan hijauan non-leguminosa. Hal ini dikarenakan masing-masing hijauan pakan memiliki kandungan

Tabel 4. Fraksi $a, b, c$, dan degradasi teori (DT) dari PK bahan pakan hijauan (fraction $a, b, c$, and $C P$ degradation theory (DT) of forage feedstuffs)

\begin{tabular}{lcccc}
\hline \hline \multicolumn{1}{c}{ Nama sampel (sample name) } & $a$ & $b$ & $c$ & DT (Kp 5\%) \\
\hline Turi putih (Sesbania glandiflora) & 57,19 & 39,25 & 0,08 & $81,46^{\mathrm{a}}$ \\
Gamal (Gliricidia sepium) & 14,81 & 74,89 & 0,11 & $66,14^{\mathrm{b}}$ \\
Nangka (Artocarpus heterophyllus) & 26,75 & 46,34 & 0,04 & $47,05^{\mathrm{c}}$ \\
Beringin (Ficus benjamina) & 28,88 & 29,25 & 0,05 & $42,89^{\mathrm{d}}$ \\
Sawo (Manilkara zapota) & 22,42 & 25,33 & 0,03 & $32,49^{\mathrm{e}}$ \\
Kaliandra (Calliandra calothyrsus) & 16,42 & 40,29 & 0,03 & $31,84^{\mathrm{e}, \mathrm{f}}$ \\
Coklat (Theobroma cacao L.) & 21,00 & 21,67 & 0,03 & $29,46^{\mathrm{f}}$ \\
\hline
\end{tabular}

$\overline{\mathrm{a}, \mathrm{b}, \mathrm{c}, \mathrm{d}, \mathrm{e}, \mathrm{f}}$ Superskrip yang berbeda pada kolom yang sama menunjukkan adanya perbedaan yang nyata $(\mathrm{P}<0,05)$ (different superscripts at the same column indicate significant differences $(P<0.05)$ ). 
Tabel 5. Fraksi $a, b, c$, dan degradasi teori (DT) dari NDF bahan pakan hijauan (fraction $a, b$, $c$, and the degradation theory (DT) NDF of forage feedstuffs)

\begin{tabular}{lcccc}
\hline \hline \multicolumn{1}{c}{ Nama sampel (sample name) } & $a$ & $b$ & $c$ & DT (Kp 5\%) \\
\hline Turi putih (Sesbania glandiflora) & 11,28 & 74,51 & 0,08 & $56,69^{\mathrm{a}}$ \\
Coklat (Theobroma cacao L.) & 35,01 & 33,52 & 0,08 & $55,43^{\mathrm{a}}$ \\
Gamal (Gliricidia sepium) & $-19,07$ & 99,19 & 0,10 & $46,84^{\mathrm{b}}$ \\
Sawo (Manilkara zapota) & 37,10 & 18,27 & 0,05 & $46,59^{\mathrm{b}}$ \\
Beringin (Ficus benjamina) & 35,25 & 17,36 & 0,05 & $44,18^{\mathrm{b}}$ \\
Nangka (Artocarpus heterophyllus) & 14,47 & 33,31 & 0,04 & $30,07^{\mathrm{c}}$ \\
Kaliandra (Calliandra calothyrsus) & 14,74 & 24,83 & 0,03 & $23,01^{\mathrm{d}}$ \\
\hline a,b,c,d Superskrip yang berbeda pada kolom yang sama menunjukkan adanya perbedaan yang nyata $(\mathrm{P}<0,05)$ &
\end{tabular}

dinding sel yang berbeda-beda. Kandungan dinding sel suatu tanaman tergantung pada bagian dari tanaman dan umur pemotongan yang merupakan salah satu faktor terpenting yang dapat mempengaruhi kandungan nutrien hijauan. Pada pakan gamal fraksi $a$ yang negatif yaitu $-19,07$, menunjukkan adanya waktu tunda (lag fase). Menurut Orskov (1992), jika ada nilai $a$ negatif, ini terjadi jika hanya sedikit atau tidak ada sama sekali bahan yang terlarut dan fase lag terjadi sebelum proses degradasi berlangsung.

Adanya perbedaan nilai $a, b, c$, dan DT antara jenis hijauan leguminosa dapat disebabkan karena perbedaan komposisi nutrien. Menurut Thomaszewska et al. (1993), bagian terbesar dinding sel adalah selulosa, hemiselulosa, dan lignin, dimana terdapat selulosa yang potensial tercerna dan yang tidak dapat dicerna (lignoselulosa). Kualitas suatu bahan pakan juga ditentukan oleh komposisi kimianya, disamping juga dipengaruhi oleh ada tidak atau besar kecilnya anti kualitas atau anti nutrisi pada bahan pakan tersebut (Soejono et al., 2002). Puncak fermentasi bahan selain dinding sel sekitar 4 jam setelah makan, sedangkan jumlah maksimum selulosa yang dicerna terjadi antara 6-18 jam setelah makan (Van Soest, 1994). Menurut Lopez et al. (2000), kandungan NDF pada hijauan dapat memberikan pengaruh terhadap kecernaan berkisar antara $45-80 \%$.

Degradasi maksimum $(a+b)$ untuk fraksi NDF hijauan pakan turi putih, coklat, gamal, beringin menunjukkan hasil yang mendekati maksimum, karena nilai $(a+b)$ hampir mendekati nilainya pada inkubasi 48 jam (TP: $85,79 \%$ vs $84,19 \%$; CO: $68,52 \%$ vs $67,81 \%$; GL: $80,12 \%$ vs $79,30 \%$; dan BR: $52,61 \%$ vs $51,03 \%$ ). Untuk sawo, nangka, dan kaliandra nilai $(a+b)$ lebih besar daripada kinetika kehilangan pada inkubasi 48 jam (SW: $55,71 \%$ vs $53,71 \%$; NG: $47,79 \%$ vs $42,90 \%$; dan KL: $39,57 \%$ vs $33,69 \%$ ). Hal ini menunjukkan bahwa belum terjadi degradasi secara maksimum pada hijauan pakan sawo, nangka, dan kaliandra sehingga masih membutuhkan waktu $>48$ jam untuk maksimal degradasinya NDF.

Degradasi acid detergent fiber. Nilai DT degradasi ADF menunjukkan adanya perbedaan nyata $(\mathrm{P}<0,05)($ Tabel 6$)$. Nilai fraksi yang mudah larut $(a)$ dan fraksi yang potensial terdegradasi $(b)$ serta laju fraksi yang potensial terdegradasi (c) dan DT dari c tersaji pada Tabel 6. Dilihat dari nilai DT ke tujuh jenis hijauan pakan, maka bahan pakan coklat mempunyai nilai DT sebesar $69,15 \%$ kemudian diikuti oleh gamal sebesar $61,27 \%$, turi putih sebesar 56,53\%, nangka sebesar $44,66 \%$ sawo sebesar 43,95\%, beringin sebesar $40,11 \%$, dan kaliandra merupakan salah satu jenis leguminosa yang memiliki nilai DT yang terendah yaitu sebesar $21,08 \%$.

Tujuh jenis hijauan pakan baik jenis leguminosa maupun hijauan non-leguminosa memiliki kandungan nutrien ADF yang berbeda-beda sehingga dapat mempengaruhi nilai dari fraksi $a, b$, $c$, dan DT (Tabel 6). Dengan demikian terlihat bahwa persentase kehilangan ADF pada bahan pakan leguminosa tidak selalu lebih tinggi dari bahan pakan hijauan non-leguminosa. Hal ini dikarenakan masing-masing hijauan pakan memiliki kandungan isi sel yang berbeda-beda. Adanya perbedaan nilai $a, b, c$, dan DT antara jenis hijauan leguminosa dapat disebabkan karena perbedaan komposisi nutrien. Kandungan ADF merupakan faktor pembatas kecernaan. ADF di dalam pakan memberikan korelasi negatif terhadap degradasi masing-masing hijauan pakan. Tingginya kadar fraksi serat pada pakan, selain itu lignifikasi pada tahap lebih lanjut juga dapat mengurangi aktivitas degradasi pakan oleh mikrobia rumen, besarnya kandungan lignin tentu saja secara tidak langsung akan memperkecil laju degradasi fraksi potensial terdegradasi (Khazaal et al., 1995). Menurut Van Soest (1994), ADF memberikan pengaruh yang tinggi pada kecernaan hijauan berkisar antara 7588\% dan kandungan ADF pada pasture digunakan sebagai indeks untuk memprediksi tingkat 
Tabel 6. Fraksi $a, b, c$, dan degradasi teori (DT) dari ADF bahan pakan hijauan (fraction $a, b, c$, and ADF degradation theory (DT) of forage feedstuffs)

\begin{tabular}{lrccc}
\hline \hline \multicolumn{1}{c}{ Nama sampel (sample name) } & \multicolumn{1}{c}{$a$} & $b$ & $c$ & DT (Kp 5\%) \\
\hline Coklat (Theobroma cacao L.) & 52,79 & 27,88 & 0,07 & $69,15^{\mathrm{a}}$ \\
Gamal (Gliricidia sepium) & 5,44 & 77,63 & 0,13 & $61,27^{\mathrm{b}}$ \\
Turi putih (Sesbania glandiflora) & 11,40 & 72,31 & 0,08 & $56,53^{\mathrm{c}}$ \\
Nangka (Artocarpus heterophyllus) & 15,65 & 49,16 & 0,07 & $44,66^{\mathrm{d}}$ \\
Sawo (Manilkara zapota) & 27,16 & 28,96 & 0,07 & $43,95^{\mathrm{d}}$ \\
Beringin (Ficus benjamina) & 26,40 & 33,31 & 0,04 & $40,11^{\mathrm{e}}$ \\
Kaliandra (Calliandra calothyrsus) & 1,60 & 39,37 & 0,05 & $21,08^{\mathrm{f}}$ \\
\hline
\end{tabular}

$\overline{\mathrm{a}, \mathrm{b}, \mathrm{c}, \mathrm{d}, \mathrm{e}, \mathrm{f}}$ Superskrip yang berbeda pada kolom yang sama menunjukkan adanya perbedaan yang nyata $(\mathrm{P}<0,05)$ (different superscripts at the same column indicate significant differences $(P<0.05)$ ).

kecernaan pasture. Terjadinya perbedaan hasil ini dapat disebabkan karena adanya perbedaan sampel bahan pakan yang digunakan.

Degradasi maksimum $(a+b)$ untuk fraksi ADF hanya hijauan pakan coklat, gamal, turi putih, nangka, dan sawo menunjukkan hasil yang mendekati maksimum, karena nilai $(a+b)$ hampir mendekati nilainya pada inkubasi 48 jam (CO: $80,67 \%$ vs $79,70 \%$; GL: $83,07 \%$ vs $82,92 \%$; TP: $83,71 \%$ vs 82,16\%; NG: $64,80 \%$ vs $63,10 \%$; dan SW: $56,12 \%$ vs $55,11 \%)$. Untuk beringin dan kaliandra nilai $(a+b)$ lebih besar daripada kinetika kehilangan pada inkubasi 48 jam (BR: 59,71\% vs 54,83\%; dan KL: $40,97 \%$ vs $37,40 \%$ ), hal ini menunjukkan bahwa belum terjadi degradasi secara maksimum. Untuk itu pada hijauan pakan beringin dan kaliandra masih harus membutuhkan waktu lebih dari 48 jam untuk mendegradasi nutrien ADF.

\section{Kesimpulan}

Tanaman leguminosa turi putih, gamal, dan kaliandra memiliki nilai degradasi teori fraksi BK, BO, PK, NDF, dan ADF tidak selalu lebih tinggi daripada tanaman non-leguminosa (nangka, beringin, sawo, dan coklat). Ada kecenderungan bahwa makin lama waktu tinggal di dalam rumen maka degradasinya akan semakin meningkat.

\section{Daftar Pustaka}

AOAC. 2005. Official Methods of Analiysis of The Association of Official Analytical Chemists. Published by the Association of Official Analytical Chemists, Maryland, USA.

Hartadi, H., Kustantinah, R.E. Indarto, N.N. Dono, dan Zuprizal. 2008. Bahan Ajar : Nutrisi Ternak Dasar PTN 1301/2-1. Bagian Nutrisi dan Makanan Ternak. Fakultas Peternakan Universitas Gadjah Mada. Yogyakarta.

Jung, H.D., D. Buxton, R. Hatflied, D. Mertens, J. Ralph, and P. Wermer. 1996. Improving forage fibre digestibility. Feedmix 4(6): 3033.

Khazaal, K.M.T. Dentinho, J.M. Ribeiro, and E.R. Orskov. 1995. Prediction of apparent digestibility and voluntary intake of hays fed to sheep: Comparison between using fibre component, in vitro digestibility or characteristics of gas production or nylon bag degradation. British Soc. Anim. Sci. 61: 527538.

Kustantinah. 2008. Ransum Ruminansia PTN 3304. Bagian Nutrisi dan Makanan Ternak. Fakultas Peternakan Universitas Gadjah Mada. Yogyakarta.

Lopez, S., J. Dijkstra, and J. France. 2000. Predition of energy supply in ruminant with emphasis forage. CAB International, Wallingford, UK, pp: 63-94.

Orskov, E.R. 1992. Protein Nutrition in Ruminant Academic Press Ltd. London.

Soejono, M., R. Utomo, S.P.S. Budi, dan A. Agus. 2002. Mutu pakan sapi potong ditinjau dari kebutuhan nutrisi. Makalah disampaikan pada pertemuan Pengawas Mutu Pakan Ternak Dinas Peternakan Propinsi Jawa Timur, Surabaya.

Tomaszewska, M.W., I.M. Mastika, A. Djajanegara, S. Gardiner, dan T.R. Wiradarya. 1993. Produksi Kambing dan Domba di Indonesia. Sebelas Maret University Press. Surakarta.

Van Soest, P.J. 1994. Nutritional Ecology of The Ruminant. $2^{\text {nd }}$ ed. Comstock Publishing Associates. A. Division of Cornell University Press. Ithaca and London. 